\title{
Noile paradigme ale secularizării
}

\author{
Andrei CRIȘAN*
}

Abstract: In this article we've tried to analyze the new coordinates which redefine the identity of the phenomenon of secularization. This phenomenon, we cannot say that is outdated or that it is linear, but has suffered some "paradigm" changes. New paradigms don't turn society "atheist" but diversify it (religiously) so much so, that traditional religions are no longer able to keep up with new religious movements. Nowadays man no longer removes religion from society but returns it, in a different form given by his own whims. Every person has the right to choose the form of religiosity that suits them. Man is not in the service of religion but religion in his service. Transcendent has value only if it serves the immanent world. Religion is no longer the window for the sacred, and the holy becomes merely a public commodity. The difference in relation to the classical forms of secularization is that now the sacred becomes revitalized, returned, but in more shapes.

\footnotetext{
*PhD Candidate, Faculty of Orthodox Theology at „1 Decembrie 1918” University in Alba Iulia, Romania.
} 
Keywords: religious market, globalization, postmodernity, religious hybridization, sociology of religion.

Secularizarea, ca orice alt fenomen socio-religios, a cunoscut și va mai cunoaște nenumărate metamorfoze, în itinerariul ei istoric. De la apariția acesteia, lumea a avut parte de o schimbare fără precedent, care s-a produs cu o rapiditate nemaiîntâlnită. În acest sens și secularizarea a căpătat o altă înfățișare, mai ales în zilele noastre, destul de diferită față de cea percepută de primii ei analiști. Cum omul nu poate să trăiască fără religie, în zonele puternic globalizate întâlnim un reviriment al sacrului favorizat de globalizare, care a adus cu sine și idei religioase care nu sunt specifice culturii și perimetrului respectiv. Accesul facil al omului postmodern la orice sistem religios, a dat naștere posibilității alegerii religiei în funție de dorința fiecărei persoane. Singurele perdante în acest proces sunt religiile tradiționale care se văd neputincioase în fața creșterii numărului de secte și mișcări cu caracter hibrid. Astfel, pericolul dezrădăcinării și negării propriei religii și chiar culturi pândește societățile super-dezvoltate, ducând la iminentul dezechilibru macro-social.

\section{Teoria clasică a secularizării}

Clasica teorie a secularizării admitea că: „,răspândirea la scară planetară a concepțiilor de stat național, democrație parlamentară, stat de drept, economie de piață liberă, știință rațională ar putea da naștere unui model similar al organizării sociale în care religia ar putea fi în mare măsură limitată la domeniul privat" a secularizării încă stă la baza celor promovate de analiștii actuali,

\footnotetext{
${ }^{1}$ Monika Wohlrab-Sahr and Marian Burchardt, Multiple Secularities: Toward a Cultural Sociology of Secular Modernities, în „Comparative Sociology”, vol. 11, Issue 3, 2012, p. 876.
} 
sociologi sau teologi, însă nu se mai bucură de o poziție dominantă².

Dincolo de evoluția temporală a secularizării, constatăm că ea se manifestă diferit și din punct de vedere spațial. Astăzi avem de-a face cu mai multe modeluri de secularizare. Majoritatea teologilor vorbesc de o secularizare excesivă întâlnită în Vestul Europei, o adevărată situație excepțională, care confirmă regula unei „lumi” destul de religioasă. Jose Casanova sintetizează cât se poate de elocvent teoria clasică a secularizării. El încearcă să reliefeze impactul secularizării în antroplogie și comportamentul religios, autonomizarea domeniilor de activitate în societate și trecerea religiei în mediul privat:

Secularizarea este percepută ca declinul credințelor și practicilor religioase în societățile moderne, deseori postulată ca un proces uman, universal și de dezvoltare. Această definiție este larg răspândită în abordările academice europene, referitoare la termenul secularizare.

Secularizarea ca privatizare a religiei, de cele mai multe ori înțeleasă ca un trend general istoric de natură modernă, dar în același timp și ca o veritabilă pre-condiție pentru modelele democratice liberale moderne

Secularizarea ca diferențiere a sferelor seculare, îțeleasă de obicei ca „emancipare” de sub influența instituțiilor și normelor religioase. Acesta ar fi înțelesul de bază al termenului secularizare, care se apropie cel mai mult de înțelesul original și istoric al lui. Această ultimă definire, este inclusă în aproape toate dicționarele limbilor vest-europene ${ }^{4}$.

\footnotetext{
${ }^{2}$ Ibidem, p. 877.

${ }^{3}$ Pentru o mai nuanțată caracterizare a ,privatizării” religiei, este de preferat cartea lui Jose Casanova Public Religions in the Modern World, Chicago: University of Chicago Press, 1994 și deasemenea Thomas Luckmann, The Invisible Religion: The Problem of Religion in Modern Society, New York, 1967, Macmillan.

${ }^{4}$ Jose Casanova, Rethinking Secularization: A Global Comparative Perspective, în „The Hedgehog Review”, vol. 8, Spring - Summer, 2006, nr. 1-2, p. 7.
} 


\section{Noile paradigme ale secularizării}

Noile paradigme se leagă în mare măsură de existența mai multor modernități. Multitudinea de modernități văd secularizarea ca o adevărată „,cheie a succesului”. Cu siguranță că ideea de succes la care trebuie să ajungă o societate este fabricată de „cultura secularistă occidentală". Pentru a se alinia la standardele propuse de Apus, societățile non-occidentale împrumută secularizarea „de dragul” unei integrări în ceea ce numește Hans Kung „weltethos”, în ethos-ul mondial proliferat de către nord-atlantici. Astfel, Monika Wohlrab-Sahr și Marian Burchardt disting patru cauze ale implementării secularității: „1) secularitate de dragul drepturilor și libertăților individuales; 2) secularitate de dragul echilibrării / pacifizării diversității religioase; 3) secularitate de dragul integrării și dezvoltării naționale sau sociale și 4) secularitate de dragul dezvoltării independente domeniilor funcționale ale societății”'.

Societățile lumii civilizate de astăzi „se folosesc” de secularizare în scopul propășirii materialismului și raționalismului adânc întipărite în mentalul colectiv al oamenilor. Cultura raționalistmaterialistă a dat naștere secularismului, acesta din urmă întorcându-i serviciul prin strașnicul servilism (față de cultura occidentală) de care dă dovadă. $\mathrm{Cu}$ toate acestea, mariajul dintre societate și secularism

\footnotetext{
${ }^{5}$ Problema libertății omului este cea mai profundă dintre toate. Dintre toate religiile existente pe pământ creștinismul este religia care conservă cel mai bine libertatea omului. Dacă triumful lui în istorie poate să fie datorat unei caracteristici anume, cu siguranță că optica despre libertate rămâne atu-ul principal. Însăși provindeța creștină postulează un Dumnezeu iubitor care păstrează și protezează cu orice risc libertatea omului. Când omul a sesizat denaturatea imaginii unui Dumnezeu preocupat de libertatea omului de către Biserică, prin încălcarea într-un mod instituționalizat a ei (libertății omului), acesta din urmă și-a creat o pseudo-religie numită secularism care să păstreze pe mai departe liberul arbitru. Evident că orice formă de libertate care nu își trage „seva” din „transcendent” rămâne iluzorie. Acest secularism este un „rău” provocat de un ,rău instituționalizat”.

${ }^{6}$ Monika Wohlrab-Sahr and Marian Burchardt, art. cit., p. 889.
} 
pare să dea semne de slăbiciune, mai ales în ultima perioadă, când datele statistice evocă o ,reîntoarcere a sacrului”. Numai că, noul val de religiozitate are coordonate diferite și este greu de îțeles de către teoreticienii secularizării care asociază veridicitatea religiozității cu prezența în sfera socială, omițând faptul că poate să existe o religiozitate individualizată․ Privatizarea religiei în ultima perioadă nu mai înseamnă, așa cum era în trecut, un anumit tip de indiferentism religios, ci după cum sesizează Brunetto Salvarani, asistăm la pierderea influenței religiilor tradiționale asupra conștiinței omului: „Teoria banalizată despre secularizare vorbește despre indiferentismul religios, în timp ce avem de-a face cu o scăpare a convingerilor religioase de sub stăpânirea religiilor tradiționale, până la neîncrederea fățișă"s.

În ceea ce privește prezența religiei în sfera politicului nu putem să nu constatăm o oarecare stare conflictuală între religie și sistemele politice. Implicarea religiei în arealul politic, dar și secularizarea excesivă a politicului, generează curente de tip fundamentalist care încearcă să corecteze derapajele societății, ceea ce denotă o afirmare a religiozității crescânde a societății ${ }^{9}$. Religia începe să-și exprime indignarea față de politica secularizată excesiv, reprezentând o provocare la adresa acesteia. Prin urmare, nu este exclusă o revalorizare a identității religioase, ca efect al presiunii exercitate asupra statelor seculare, de către facțiunile conservatoare ale religiilor. Ipotetică este și apariția unor set de legi care să garanteze sau chiar să favorizeze libertatea religioasă. Așadar, putem asista în următoarea perioadă la un nou tip de secularism, unul defensiv.

Pe plan antropologic, religia „deservește” atât de mult persoana

${ }^{7}$ Gert Pickel, Contextual Secularization. Theoretical Thoughts and Empirical Implications, în „Religion and Society in Central and Eastern Europe”, vol. 4, nr. 1, 2011, p. 7.

${ }^{8}$ Brunetto Salvarani, Il Fattore $R$. Le religioni alla prova della globalizzazione, Bologna, Edit. Eni, 2012, p. 75.

${ }^{9}$ Gert Pickel, art. cit., p. 8. 
umană, încât la un nivel macro este imposibil ca religia să dispară. Ea se poate diminua în intensitate însă poate să dispară concomitent cu ființa umană. În conformitate cu afirmația lui Gert Pickel potrivit căreia ,persoanele devin religioase datorită nevoii de a face față situațiilor neprevăzute" 10 putem afirma că atâta timp cât omul se simte nesigur în fața ,itinerariului” său în lume, religia nu are cum să dispară. Pe de altă parte, religia este necesară și datorită faptului că reprezintă ,seva” devenirii sale, însă astăzi omul nu poate să înlăture în totalitate religia de dragul secularizării. Astfel, dacă în societatea tradițională era o religie dominantă, astăzi vorbim despre o multitudine de religii care oferă noi oportunități ale devenirii omului: „Noi trăim astăzi într-o lume caracterizată nu neaparat de lipsa religiei, ci de o multiplicitate a opțiunilor religioase și de apariția de noi forme de spiritualitate și religiozitate, de care se alipesc grupuri răzlețe sau indivizi, pentru a da un sens propriei vieți și a forma aspirații proprii" ". Secularizarea a selectat din fiecare religie elemente care sunt utile omului însă le-a despuiat de „haina” religioasă. Spre exempu, în ultimii ani, se vorbește de preluarea unor tehnici spirituale în special în psihoterapie, cu precădere din religiile panteiste ${ }^{12}$.

În ultima perioadă se vorbește de o ,modernitate religioasă”, care îl transformă pe om în pelerin și convertit ca efect al unei religiozități în mișcare, proprie unei individualizări a credinței. Pelerin este atunci când merge în căutarea unei forme religioase „după măsura sa”, iar convertit este acela care nu se teme de trecerea granițelor altor credințe ${ }^{13}$. Printre noile particularități ale secularizării

${ }^{10}$ Ibidem, p. 12.
${ }^{11}$ Brunetto Salvarani, op. cit., p. 130 .
${ }^{12}$ Acest aspect ne provoacă să constatăm că între psihoterapie și spiritualitate
diferența este difuză. Chiar dacă o persoană se declara atee, are posibilitatea
să practice, în cadrul psihoterapiei, tehnici yoga. Acest aspect argumentează
tendința omului de a edifica acea ,piață religioasă” în care ai acces la orice
constituent care ,ți se potrivește”.
${ }^{13}$ Enzo Pace, L' oggetto assente. La seccolarizzazione: dalle origini della 
regăsim și posibilitatea omului de a-și alege rațional credința (rational choice). Aceasta se explică prin cuantificarea „profitului” pe care „clientul religios” îl obține în urma diferenței dintre cost și beneficiu. Dacă o anumită credință oferă multiple beneficii cu costuri puține atunci are mari șanse să fie acceptată. În acest fel au de pierdut credințele mai rigide în favoare celor permisive ${ }^{14}$. Pericolul acesta le pândește pe aproape toate religiile lumii. Multe sunt pe cale să accepte compromisuri de neimaginat pentru a nu pierde numărul aderenților, riscând periclitarea identității.

Conștientizarea (de către om) unei conditio humana limitată și perfectibilă, jinduitoare spre un ajutor venit din transcendent rămâne argumentul forte împotriva dispariției religiei. Se pare că asigurarea unui trai decent, și independent i-a dat omului senzația că poate să preîntâmpine orice stenahorie doar prin propriile forțe. Această filosofie ,își trage seva" din umanism și din celelalte curente care au escamotat condiția umană ${ }^{15}$ ',

sociologia delle religioni agli sviluppi teorici recenti, în „Ritorno delle fedi, crisi della secolarizzazione? Dall' eta degli estremi al nuovo millennio”, a cura di Vicenzo Lavenia, Revista semestrale dell' Istituto storico di Modena, Modena, 2010, p. 171.

${ }^{14}$ Ibidem, p. 172.

${ }^{15}$ În lumea dezvoltată există practica efectuarea unor asigurări pentru orice tip de intemperie în care viața și existența omului sunt puse în pericol. Siguranța existențială creată în ultima vreme nu antrenează necesitatea „apelării” la un ajutor divin. Problema sensibilă rămâne moartea, care (încă) nu poate să fie depășită, ci doar cosmetizată sau marginalizată. Totuși, omul în fața morții nu face abstracție de întrebările esențiale ale vieții (cine suntem?... de unde venim? ... unde mergem?), întrebări la care, religia are pretenția, că răspunde. Moartea rămâne pentru totdeauna marea provocare pentru secularizare. Cât timp există moartea, secularizarea rămâne o utopie, devenind (moartea) pentru aceasta din urmă un adevărat antidot. Atunci când omul nu mai percepe propria existență și lumea ca taine, înlocuindu-le cu raționalizarea excesivă, religiozitatea are de suferit, dar fără să dispară. Religia rămâne în această situație, un bun colectiv la care poate avea acces fiecare om, dar într-un mod individual. Pentru această 
În zilele noastre pluralitatea religioasă pare să meargă ,cap la cap" cu secularizarea. Când spun acest lucru nu mă refer la existența mai multor grupuri religioase în aceeași societate, ci la pluralizarea religioasă suscitată de individualizarea religiei. În acest sens, Charles Taylor spunea că: „noi credem că secularismul sau „,laicite” nu are de-a face cu relația dintre religie și stat, în timp ce, în fapt, are de-a face cu un răspuns corect din partea statului democratic față de diversitate" ${ }_{16}$. Noul val de ateism propune un minim talâm religios, care diferă de a o persoană la alta, dar care se asociază deseori cu ateismul chiar dacă nu corespunde termenului în totalitate ${ }^{17}$. Astăzi, se poate spune că în rândul ateilor se includ și cei care se dezic de formele religioase tradiționale, dar care dezvoltă o formă originală de religiozitate. Din această cauză Noile Mișcări Religioase proliferează în societatea așazis secularizată. Misiologul Brunetto Salvarani este de părere că ,în cele din urmă, secularizarea nu înseamnă neapărat, sfârșitul religiei ci mai degraba pluralizarea religiilor, acompaniată de dez-europenizare a creștinismului, care denotă un final al monopolului (religios n.n.) occidental”'18. Cu toate acestea, părerea noastră este că din punct de vedere numeric, vor fi variații sau chiar diminuări în ceea ce privește efectivul adepților religiilor tradiționale, migrând spre religii de tip hibrid, însă Dumnezeu nu va dispărea din viața omului niciodată. De aceeași părere este și Zygmunt Bauman care afirmă că: „Cred că

situație „nu este de vină” Dumnezeu, ci omul, care a ales să-și fie luiși dumnezeu. Frământarea noastră este legată de aparenta lipsă de promptitudine din partea lui Dumnezeu, care acționează în mod diferit comparativ cu alte epoci.

${ }^{16}$ Charles Taylor, The meaning of secularism, în „Hedgehog Rev”, nr. 12, 2010, apud Paul Morris, Multiculturalism, Rights and Religion: The Individual's Human Right to Participate and Belong, în „Cultural, Religious and Political Contestations. The Multicultural Challenge”, Fethi Mansouri (editor), Heidelberg New York Dordrecht London, Springer International Publishing, 2015, p. 33.

${ }^{17}$ Gert Pickel, art. cit., p. 12.

${ }^{18}$ Brunetto Salvarani, op. cit., p. 33. 
Dumnezeu va muri cu umanitatea, și nu cu o clipă înaintea ei”19.

\section{Concluzie}

Omul și-a dat seama că a căzut într-o situație nefavorabilă istoriei sale pe acest pământ, prin refuzarea religiei. Chiar dacă a reușit proiecte tehnice spectaculoase, totuși esența existenței nu este facilitarea vieții pe pământ, ci devenirea personală, care este posibilă doar prin îmbrățișarea sacrului. Aparenta îndulcire a secularizării a „fabricat” un bun comun numit religie, care nu se diferențiază prea mult de orice alt element vandabil sau cumpărabil și care poate fi transformat după bunul plac al fiecăruia. În tot acest proces, religiile tradiționale sunt în defensivă, deoarece pe lângă pierderea de adepți se conturează și apariția de noi mișcări religioase desprinse din sânul acestora, cu instinct relativizant față de „religiile - mamă”.

\section{Bibliografie:}

1. Bauman, Zygmunt, Vite che non possiamo permetterci conversazioni con C. Rovirosa-Madrazo, trad. di M. Cupellaro, Roma-Bari, Laterza, 2011.

2. Casanova, Jose, Rethinking Secularization: A Global Comparative Perspective, în „The Hedgehog Review”, vol. 8, Spring - Summer, 2006, nr. 1-2.

3. Pace, Enzo, L'oggetto assente. La seccolarizzazione: dalle origini della sociologia delle religioni agli sviluppi teorici recenti, în „Ritorno delle fedi, crisi della secolarizzazione? Dall' eta degli estremi al nuovo millennio", a cura di Vicenzo Lavenia, Revista semestrale dell' Istituto storico di Modena, Modena, 2010.

4. Pickel, Gert, Contextual Secularization. Theoretical Thoughts and Empirical Implications, în „Religion and Society in Central and Eastern Europe", vol. 4, nr. 1, 2011.

${ }^{19}$ Zigmunt Bauman, Vite che non possiamo permetterci-conversazioni con $C$. Rovirosa-Madrazo, trad. di M. Cupellaro, Roma-Bari, Laterza, 2011, p. 147. 
5. Salvarani, Brunetto, Il Fattore $R$. Le religioni alla prova della globalizzazione, Bologna, Edit. Eni, 2012.

6. Taylor, Charles, The meaning of secularism, în „Hedgehog Rev”, nr. 12, 2010, apud Paul Morris, Multiculturalism, Rights and Religion: The Individual's Human Right to Participate and Belong, în „Cultural, Religious and Political Contestations. The Multicultural Challenge”, Fethi Mansouri (editor), Heidelberg New York Dordrecht London, Springer International Publishing, 2015.

7. Wohlrab-Sahr, Monika, and Marian Burchardt, Multiple Secularities: Toward a Cultural Sociology of Secular Modernities, în „Comparative Sociology”, vol. 11, Issue 3, 2012. 